\title{
THE GENIUS OF SHAKESPEARE'S "PLAGIARISMS". CASE STUDIES: HAMLET, OTHELLO, KING LEAR AND MACBETH
}

\author{
CODRIN LIVIU CUȚITARU* \\ Alexandru Ioan Cuza University of Iaşi, Romania
}

\begin{abstract}
This paper aims at exploring the cultural ambiguity which William Shakespeare remarkably extracts from the sources of his major plays, turning it, eventually, into an essential instrument of the tragic and the tragedy. What in normal/modern circumstances would easily count as "plagiarism", becomes here, paradoxically, a token of artistic genius and brilliant creation. Our examples will be from the four outstanding tragedies-Hamlet, Othello, King Lear and Macbeth. The sources selected by our research will be Saxo Grammaticus's Histoires tragiques, Cinthio's Un Capitano Moro, the Celtic legend Leir of Britain and, obviously, Holinshed's Chronicles. We shall try to demonstrate that the so-called cultural ambiguity adopts various forms in Shakespeare's plays, going from the clash of civilisations (Hamlet and Othello) to the crisis of identity (Lear and Macbeth).
\end{abstract}

Keywords: cultural ambiguity; identity; cultural clash; Hamlet; Othello; King Lear; Macbeth; Saxo Grammaticus; Raphael Holinshed; Geoffrey of Monmouth; Cinthio.

In present-day standards, many of Shakespeare's plays would be susceptible of plagiarism. Evidently, ad litteram interpreting the term: as an appropriation of someone else's work. Bluntly put, this is what Shakespeare "does" when he makes use of sources for his masterpieces. He takes plots, characters, contexts and even ideas from his contemporaries or predecessors and turns them into personal literary pieces. Is it acceptable? According to the world literary history, yes. And this is so because the greatest writer of all times does not merely reproduce, in his work, old "facts" in new "forms", but he invests sometimes

\footnotetext{
*claura@uaic.ro
}

DOI: 10.1515/lincu -2017-0006 
dull stories with remarkable significances and rebuilds otherwise irrelevant instances of life as allegories of unsurpassed beauty. Should one compare, even superficially, Shakespeare's tragedies and comedies with their sources of inspiration, one will inevitably arrive at such a conclusion: the artistic genius of the author of the Sonnets bursts out from each and every detail of his "plagiarized" fragments. It is, in fact, the aim of this paper to demonstrate thatwithin the sources of his major tragedies (Hamlet, Othello, King Lear and Macbeth) - Shakespeare located meaningful nuances that originally had escaped the hermeneutical skills of their respective authors. We shall try to illustrate how at least one of these nuances has actually become a hallmark of aesthetic singularity and symbolic uniqueness for all the above-mentioned plays. It is a recurrent element, which may be simply called the cultural conflict, i.e. a metatextual reality Shakespeare deciphered, in various representations, in the historical archetypes of Hamlet, Othello, King Lear and Macbeth and then transformed into an instrument of the tragic. Our initial hypothesis - to be confirmed, hopefully, by our later analysis - claims that the protagonists of Shakespeare's major tragedies are, at their profoundest levels of consciousness, the prisoners of a psychological antagonism with cultural connotations (basically related to identity and mentality issues!). This impossible to reconcile conflicta "war", in reality - ultimately generates the tragedy.

Hamlet (1602), for example, is inspired by the chronicles of the medieval historian Saxo Grammaticus, gathered in the 1200 collection Gesta Danorum, or, possibly, by a more recent French version of them, given (with few modifications of the original text) by François de Belleforest in 1570 and entitled Histoires Tragiques. Obviously, the legend of the Northern prince willing to revenge his father's unjust death had been circulating, according to many researchers, ever since the Indo-European mythology. It is believed that the medieval historian from Gesta Danorum used as a source for his story a Scandinavian poem which did not survive. Anyway, the myth of the hero who pretends to be a fool just to succeed in getting back at the tyrannical king appears in numerous European folklores. Saxo Grammaticus reports it in the narrative of prince Amleth who fakes imbecility in front of his uncle, Feng, in order to prepare silently his bitter revenge on him. The revenge is dictated by Feng's assassination of his own brother (Amleth's father and former king) and the taking of the throne by force. Moreover, Feng marries his sister-in-law, Gerutha (Amleth's mother), suggesting that he thus rescued her from an oppressive marriage. The curiosity of this old narrative derives from the fact that Feng's murder constitutes public knowledge. He does not only admit openly the fratricide, but he passionately motivates it. Shakespeare changes that, although, otherwise, he did not hesitate to adopt the fundamental directions of the initial story and even some of the names of the leading characters (e.g. Hamlet and Gertrude). We should ask ourselves why? Why did the playwright feel gradual 
cognitive development in the matter of the crime would be an aspect he had to introduce in his own version of "Amleth"? Why was he presumably disturbed by this single detail of Grammaticus's histoire tragique when he found so many other (important) elements of dramatic construction from the original text perfectly acceptable in his play and compatible with the expectations of his $17^{\text {th }}$ century audiences? Answering these questions may open the door to the understanding of the genius of Shakespeare's "plagiarisms".

Let us note that Hamlet learns the truth of his father's death with difficulty and after extreme, unnatural manifestations of what passes for the Invisible Universe: the ghost of the former king haunts the castle of Elsinore so as to establish a sort of transcendental contact with his still living son. It is true however that, before the revelation of the horrendous mystery of the father's death, the prince already showed despisal for the new king, Claudius, making an illustrative observation at the beginning of the play: "So excellent a king (Hamlet the father, a.n.) - that was to this (Claudius, a.n.), / Hyperion to a satyr" (Hamlet 1.2.139-40). He seems to hate Claudius for marrying his sister-in-law (his own mother), only one month after the former king's passing. Hamlet is not willing therefore to listen to Gertrude's advice derived from the experience of the worldly wisdom:

Good Hamlet, cast thy nighted color off,

And let thine eye look like a friend on Denmark.

Do not forever with thy vailed lids

Seek for thy noble father in the dust:

Thou knowst 'tis common - all that lives must die,

Passing through nature to eternity. (Hamlet 1.2.68-73)

Nor is he eager to understand Claudius's "lectures" of Realpolitik (the uncle explains transparently to the nephew that the marriage to Gertrude will ensure, among other good things, Hamlet's own succession to the throne of Denmark!). He considers Claudius a degenerate. So, it is somewhat self-understood that the ghost's full disclosure of the killing does not come as an utter surprise. Not accidentally, Hamlet exclaims at the end of his father's morbid confession: "O my prophetic soul!" (Hamlet 1.5.40). Yet, in spite of all, for no obvious reason, Shakespeare chose to transform, in his play, the element of the former king's death into an enigmatic situation revealed step by step to the protagonist (one should not omit, either, the fact that Hamlet is eventually the only one to actually know the truth, all the other characters of the tragedy - except, maybe, for Horatio who must live to tell the story! - remaining in a "safe area" of sweet ignorance). Something more significant than we may think at the first reading of the text seems to be concealed here, something Shakespeare did not want us to miss. 
One thing that immediately indicates the importance of this process of "gradual knowledge" is the very change of the protagonist himself. The outcome of the revelation of Claudius's murder coincides, paradoxically, with Hamlet's transformation. The prince no longer looks determined, brave and firm in his opinions, i.e. the way he appeared to be in the first scenes of the play. Suddenly, he has become hesitant, uncertain and prone to pessimistic meditation. What happened? Evidently, he inferred a more complex reality from the disclosure of the truth than the mere idea of a revenge. Consequently, he has turned into the "problematic" Hamlet T. S. Eliot was fascinated with. In order to comprehend the sense of this unexpected transformation we must clarify what exactly Hamlet learns from the encounter with the ghost of his father. Doing so, we should realize that at least two things may have shocked the prince. Firstly, he had to be surprised by the dead king's acceptance of his sinful life and, hence, his current prison-like experience in what seems to be the Purgatory:

\author{
I am thy father's spirit \\ Doom'd for a certain term to walk the night, \\ And for the day confined to fast in fires, \\ Till the foul crimes done in my days of nature \\ Are burnt and purged away. \\ But that I am forbid to tell the secrets of my prison-house. \\ (Hamlet 1.5.9-15).
}

Young Hamlet abruptly decodes here the message that parents are not gods. He has already discovered the "frailty" of his mother's womanhood. Now he realizes his father is not, by any chance, the "Hyperion" he thought him to be. On the contrary, his moral profile may have very well corresponded, during his lifetime, to that of the "satyr" Hamlet originally associated with Claudius. History's little ironies, to say the least! Secondly, the prince understands something even more disturbing. His father returned from the dead to communicate to him a transcendental necessity: he has to revenge his unnatural death. The task must not be performed at a personal level (the "person" of the former king is not relevant any more), but at what might be called an impersonal one: the historical order (destroyed by Claudius) has to be restored. Lex talionis is the only way to do it.

Let us admit that disliking the degenerate uncle is one thing and killing him in the name of a universal necessity (people can barely decipher) is an entirely different one! Moreover, deploring the loss of a Hyperion who turns out to be a satyr could be, similarly, very traumatic. Violently, Hamlet finds himself at the crossroads of all these cultural stereotypes. Discovering that he lives in a world whose values do not make sense to him any longer is therefore the reason for Hamlet's sudden breakdown. His famous monologue "to be or not to be" is an argument in this respect: 
To be, or not to be - that is the question. Whether "tis nobler in the mind to suffer The slings and arrows of outrageous fortune, Or to take arms against a sea of troubles, And by opposing, end them? To die, to sleep, No more $[\ldots]$

Thus conscience does make cowards of us all And thus the native hue of resolution Is sicklied o'er with the pale cast of thought, And enterprises of great pith and moment With this regard their currents turn awry, And lose the name of action. (Hamlet 3.1.56-61, 83-88).

The prince is not a coward per se, as various critics believed him to be and as he characterizes himself here indirectly, but a disconcerted hero trapped in a cultural dilemma: which is the real world - the one he used to know as a child or the one he has just stepped in as an adult? Psychologically speaking, Hamlet's drama is one of natural aging. Symbolically, nevertheless, his tragedy comes out of the cultural clash between what appears to be true and what actually turns out to be real. Likewise, the antagonism between the old law of retaliation and the new background of tolerance and forgiveness (the play is set in a Christian context!) should not be overlooked. Shakespeare had the formidable intuition of this cultural "vulnerability" in Saxo Grammaticus's Scandinavian hero. His "plagiarism" was meant to "extract" it from the depths of the mythological. Amleth does not represent strictly an archetype of Hamlet, a mere source of literary inspiration, but a pretext for an extremely sophisticated philosophical and cultural analysis. Shakespeare is Schopenhauer's archer who hits a target no one can properly see in advance.

Othello (1603), on the other hand, has as a main source of plot construction the Italian story Un Capitano Moro/A Moorish Captain written by Cinthio (Giovanni Battista Giraldi), Boccaccio's disciple, and initially published in 1565 (as part of a Decameron-like collection of tales, Gli Hecatomithi/The Hundred Myths). However, the legend of a so-called "wandering Moor", blinded by jealousy and metamorphosed into a primitive murderer, is much older than that, apparently going all the way back to a fragment from One Thousand and One Nights, entitled The Tale of the Three Apples. Anyhow, in Cinthio's story, Othello, Iago and Cassio are not given any names, being identified as "the Moor", "the Ensign" and "a Captain" respectively. Desdemona is still Disdemona. Except for his Arabian extraction, no other indication is offered by Cinthio in connection to the Moor's status in Venice. We learn that he is appreciated by the leadership of the Dukedom for his military skills. The passionate love between him and the noble Disdemona is also mentioned. There 
exists indeed a brief reference - at the beginning of the tale - that the woman's parents strove to make her change her mind about marrying the Moor, but they finally surrendered to the beautiful lady's stubbornness, accepting the facts. So, the marriage takes place and the two characters seem happy and very much in love. One significant detail was again modified by Shakespeare: in Un Capitano Moro, the Ensign (Iago) decides to punish Disdemona and not the Moor. He falls in love with his commander's wife and, since she is unresponsive, the villain begins to hate her. Let us not forget that, in Othello, Iago wants to get back at the General himself for not appointing him as his Lieutenant (even if, surprisingly, the Moor knows the Ensign's abilities)! The frustration appears to be here one of passion, whereas, in Shakespeare, it will become one of recognition. Fooled by the Ensign that Disdemona cheats on him, the Moor kills her. Reported by the honest Captain (with the Ensign's testimony), he will be imprisoned and then banished by the authorities of Venice. Later on, his wife's relatives will murder him, too. A "barbarian", Cinthio concludes, who deserved to die. Once more, William Shakespeare proves to have a keen eye, in his "plagiarizing" efforts, for the significant marginal details.

One such detail is precisely the above referred to condition of a presumed "barbarian" in a "civilized" world. We must not see the playwright's decision to change the reason of Iago's hatred, moving it from "the unfulfilled passion" to "the absence of recognition", as a random one. This constitutes the key to the understanding of the cultural conflict he attaches to Othello's story and eventually uses as an instrument of remarkable tragedy. Othello suffers-in Shakespeare's Venice-from the so-called complex of the double critique. Although cherished for his professional talents, he is still perceived as an "outcast", a "foreigner", a "primitive man" or even a "barbarian". His position in this European sophisticated system appears paradoxical (the "double critique"): he concomitantly belongs and is rejected to/by the Dukedom where he chose to live. Brabantio is appalled when he learns about his beautiful daughter's secret marriage to the Moor (albeit, ironically, he himself once admired Othello, inviting him to his home, the place where Desdemona actually met the General!). In front of the Duke, he says his daughter could not have fallen in love with "what she fear'd to look on" (Othello 1.2.98) and makes frequent racist observations upon his son-in-law. The Duke defends Othello (especially after Desdemona's confession of her deep love for the Moor), but, in privacy, seems to feel compassion for Brabantio. Therefore, it is not unexpected that Othello's affection for his wife develops symbolic manifestations. He calls her "my fair warrior" (Othello 2.1), thus transferring his own identity ("the warrior") to the woman who accepted him as a person, not just as a soldier, and taking over from her the idea of (European) beauty ("the fairness"), i.e. a sign of "integration" in the "civilized" world. Like Hamlet, Othello finds himself torn between two antagonistic spaces of identity: the "primitive" Egypt and the 
"polished" Venice. He hides a tormenting need to be accepted and recognized as a normal human being by his adoptive country. Iago's frustration consequently represents an anticipatory metaphor of his own frustration (which is, in fact, the cultural source of a tragedy of recognition). In the end, completely defeated, the Moor that he was "like the base Indian who threw a pearl away richer than all his tribe" (Othello 5.2.347-348). There could have been no better way to summarize the drama noticed by Shakespeare in Cinthio's rather superficial story.

Shakespeare shapes out similar cultural tragedies in King Lear (1606) and Macbeth (1611), simply by amplifying peripheral (yet significant) details suggested vaguely by his sources of inspiration. The same work of genius is visible in these last two major tragedies. King Lear relies on an old Celtic myth reproduced by Geoffrey of Monmouth, in the $12^{\text {th }}$ century, in his Historia Regum Britanniae/History of the Kings of Britain - Leir of Britain. Shakespeare may have used however a later version of the legend from Raphael Holinshed's The Chronicles of England, Scotland and Ireland $(1577,1587)$. Anyway, in terms of plot, this time, the playwright seems very loyal to the source-text. The names of the characters and the general contexts of the story are almost identical. Shakespeare makes one single modification in the end of the text: while, in the original historical chronicle, Lear is restored to power by his previously (unjustly) repudiated daughter, Cordelia, in the 1606 tragedy, both the British king and the French queen die in the final scene (an ending actually changed, in time, by different editors and stage directors, because it was, supposedly, too upsetting for the many readers of the play or the large audiences of viewers!). Beside the tragic decorum the author had to keep in his work by means of the death of the protagonists, the transformation had to do, again, with the cultural conflict Shakespeare decoded in the tale of Lear. One question any reader/viewer may ask here is why the king unnaturally divides his kingdom at the beginning of the play? Most of the critics blame his old age and, implicitly, his senility, but there is, in Shakespeare's symbolic approach, something deeper than that. Lear finds himself under the huge pressure of a historical desperation, which eventually reduces him to nothing - remember that the Fool tells him sadly: "I am a Fool. / Thou art nothing" (King Lear 2.5.190-191). His successors to the throne are three women who inevitably are going to start the struggle for power after his death, pushing the country to destruction. His only way to prevent this is to divide the kingdom himself among them.

The king's despair thus results from his confrontation with a patriarchal mentality (culture) that gives undeniable rights just to the male inheritor. The woman is a paria in such a world, having to fight her way inside the system. A similar cultural/gender "defect" is studied in Macbeth, a tragedy also inspired by Holinshed's Chronicles, particularly by several tales included in this collection. In short, a certain Donwald - pushed indeed, initially, by his wife—kills his 
king, Duff, as an act of revenge (the monarch murdered, at a previous moment, some members of Donwald's family). Yet, whereas, in The Chronicles, Donwald's wife is given little attention, in Shakespeare's play, Lady Macbeth has a significant part in the action, manipulating her husband and his companions very successfully at least in the opening scenes. She generates, in fact, a gender ambiguity in the text, doing the things that normally a man would do in a patriarchal universe. Her initial soliloquy offers a perfect synthesis of the situation Shakespeare creates here, only by exploring a small detail from the source-text (i.e. the presence of a woman in the "conspiracy" of men):

\author{
Come, you spirits \\ That tend on mortal thoughts, unsex me here, \\ And fill me from the crown to the toe top-full \\ Of direst cruelty! Make thick my blood, \\ Stop up the access and passage to remorse [...] \\ Come to my woman's breasts, \\ And take my milk for gall, you murdering ministers. \\ (Macbeth 1.6.41-49).
}

The world hence turns upside down, exactly like in the introductory song of the witches. Shakespeare triggers, in reality, an antagonism between two culturesthe feminine one and the masculine one (what Marilyn French convincingly calls, in her book The Late Tragedies, "the milk culture" and "the blood culture"). Within this struggle, the former has to dissimulate in order to survive (therefore, symbolically, Lady Macbeth becomes a "man"). The tragedy results naturally from this clash and it is a "cultural" one, a tragedy of (gender) identity.

In conclusion, we may say that Shakespeare's "plagiarisms" are just a pretext for sophisticated tragic constructions, in which the leading part is always played by culture and identity. This represents one of the very few cases in the history of literature when plagiarizing can be compared to a stroke of genius.

\title{
Works Cited
}

\section{Primary Sources}

Belleforest, François de. Histoires Tragiques. Paris: Laurens Chancelier, 1564. Print Cinthio (Giovanni Battista Giraldi). Gli Hecatomithi. Mondovi: Roma, 1565. Print.

Grammaticus, Saxo. Gesta Danorum. Books I-IX. Transl. by Oliver Elton. London: Marble Books, 1905. Print.

Holinshed, Raphael. The Chronicles of England, Scotland and Ireland. London: Marble Books, 1922. Print.

Monmouth, Geoffrey of. Historia Regum Britanniae/History of the Kings of Britain. Bilingual Edition. London: Marble Books, 1938. Print. 
Shakespeare, William. The Complete Works. Volume 2. Ed. Avid Bevington. London: Scott, Foresman \& Company, 1980. Print.

\section{Secondary Sources}

Eliot, T. S. "Hamlet and his Problems". Critical Theory Since Plato. Ed Hazard Adams. New York: Harcourt Brace Jovanovich College Publishers, 1992. Print.

French, Marilyn. "The Late Tragedies". Shakespearean Tragedy. Ed. John Drakakis. London \& New York: Longman, 1992. Print.

Schopenhauer, Arthur. The World as Will and Representation. Transl. by E.F.J. Payne. New York: Dover Publications, 1969. Print. 